\title{
Lectotypification of Paramollugo nudicaulis (Molluginaceae)
}

\author{
Mats Thulin
}

\begin{abstract}
THULIN, M. (2017). Lectotypification of Paramollugo nudicaulis (Molluginaceae). Candollea 72: 31-34. In English, English and French abstracts. DOI: http://dx.doi.org/10.15553/c2017v721a4

The typification of Paramollugo nudicaulis (Lam.) Thulin (三Mollugo nudicaulis Lam.) (Molluginaceae) has been problematic as no original material has been found in P. The lectotype designated here, Commerson s.n. from Mauritius, is the single specimen cited by Lamarck in the protologue, and has been located in MPU.
\end{abstract}

\section{Resumé}

THULIN, M. (2017). Lectotypification de Paramollugo nudicaulis (Molluginaceae). Candollea 72: 31-34. En anglais, résumés anglais et français. DOI: http://dx.doi.org/10.15553/c2017v721a4

La typification de Paramollugo nudicaulis (Lam.) Thulin (三Mollugo nudicaulis Lam.) (Molluginaceae) a été problématique car aucun matériel original n'a été trouvé à P. Le lectotype désigné ici, Commerson s.n. de Maurice, est le seul specimen cité par Lamarck dans le protologue. Il a été localisé à MPU.

\section{Keywords}

MOLLUGINACEAE - Mollugo - Paramollugo - Commerson - Mauritius - Typification 


\section{Introduction}

In the new taxonomy of Molluginaceae proposed by THuLIN et al. (2016), the genus Paramollugo Thulin was recognized with P. nudicaulis (Lam.) Thulin, based on Mollugo nudicaulis Lam., as type. This is a widespread species in tropical and subtropical parts of the world (Thulin et al., 2016; SukHorukov \& Kushunina, 2016). The type of Paramollugo nudicaulis was cited by Thulin et al. (2016) as "Mauritius, Commerson s.n. (?P, not located)", which is in accordance with JEFFREY (1961) and most other authors during the period 1961-2016. Exceptions are Nasir (1973) and Hedge \& Lamond (1975), who cited both the illustration "Burman, Thesaurus Zeylanicus (t. 8, f. 2)" in Burman (1737) and the Philibert Commerson (1727-1773) specimen from Mauritius as types. The aim of the present paper is to look into the typification of Paramollugo nudicaulis in more detail and to designate a lectotype.

\section{Typification}

In the protologue of Mollugo nudicaulis (LAMARck, 1797) three elements are mentioned: (1) "Alsine foliis ad radicem positis. Burm. Thes. Zeylan. p. 14.t. 8. f. 2". This refers to a drawing of a specimen of Mollugo nudicaulis from Ceylon [now Sri Lanka] in Burman (1737). This specimen collected by Paul Hermann (1640-1695) is now housed at the "Bibliothèque de l'Institut de France" in Paris (see Lourteig, 1966: 28 wrongly determined as $M$. pentaphylla L.). Johannes Burman's Thesaurus zeylanicus was mainly based on Hermann collections. These were bound in a folio volume and were donated to the "Institut de France" by Benjamin Delessert's heirs because they were regarded as a book [see Hoquet (2002) for more details on Delessert's heritage]. No collection has been located in Burman's herbarium housed in the historical herbarium G-PREL in Geneva (M.W. Callmander, pers. comm.); (2) "alsini affinis, foliis bellidis minoris, caule nudo. Sloan. Cat. p. 87. Hist. Jam. vol. 1. p. 203. t.129. f. 2". This refers to the illustration in SLOANE (1707) of a specimen of Mollugo nudicaulis from Jamaica. Sloane's phrase name was also cited as a synonym of Alsine foliis ad radicem positis by BURMAN (1737) and (3) "Cette plante croît naturellement à l'île de France, $\&$ se trouve dans l'herbier de Commerson. (V.s. in Herb. D. Thouin.)". This refers to a specimen from Mauritius collected by Commerson.

The elements (1) and (3) would clearly both be possible as a lectotype, whereas (2) is inappropriate as Sloane's figure of a plant from Jamaica ("Amérique") is just said to resemble Mollugo nudicaulis. The lectotype to prefer would be the Commerson specimen, which has long been thought to be in $\mathrm{P}$, but has not been located there. A search by the present author in P-JU and P-LA in January 2017 was also in vain.
However, according to Stafleu \& Cowan (1986) the herbarium of André Thouin, who was the head gardener and "Professeur de culture" of the Jardin des Plantes in Paris 1764-1824, is in "MPU (via J. Cambessèdes)". And, indeed, in Herb. Cambessèdes in MPU the very specimen that Lamarck studied is still extant (Fig. 1). Apart from the information on locality and collector, "Isle de france C. on", it also has the annotation "mollugo nudicaulis Dict." in Lamarck's hand. This specimen is here formally designated as the lectotype.

Paramollugo nudicaulis (Lam.) Thulin in Taxon 65 : 786. 2016.

$\equiv$ Mollugo nudicaulis Lam., Encycl. 4: 234.1797.

Lectotypus (designated here): MAURITIUS : sine loc., Commerson s.n. (MPU [MPU310690]!) (Fig. 1).

Notes. - A strange circumstance is that Paramollugo nudicaulis seems to be an exceedingly rare species on Mauritius. Apparently, the only specimen of it ever collected on Mauritius during the nearly 250 years that have passed since Commerson collected there seems to be Gueho 15575 (K), collected 23 February 1973 at Morne Brabant (Sukhorukov \& Kushunina, 2016). This opens for the possibility of some kind of confusion as regards the locality or collector of the specimen. According to Dorr (1997), Commerson's specimens "were labeled and distributed after his death and some confusion is known to have occurred with P. Sonnerat specimens". The obvious alternative origin of the type specimen would be Madagascar, where both Commerson and Sonnerat collected extensively, but any statement in that direction would have to remain speculation.

\section{Acknowledgements}

I am indebted to Caroline Loup, MPU, for locating and preparing the image of the specimen of Mollugo nudicaulis that is here designated as lectotype, to Cécile Aupic in $\mathrm{P}$ for access to the historical collections there, and to Martin Callmander for the search of specimens in G-PREL and for helpful comments on the manuscript.

\section{References}

Burman, J. (1737). Thesaurus zeylanicus. Amsterdam.

Dorr, L.J. (1997). Plant collectors in Madagascar and the Comoro Islands. Royal Botanic Gardens, Kew.

Hedge, I.C. \& J.M. LAmond (1975). Molluginaceae. In: RechingER, K.H. (ed.), Fl. Iranica 114.

Hoquet, T. (2002). La bibliothèque botanique de Benjamin Delessert. Bull. Bibliophile 2002: 100-141.

Jeffrey, C. (1961). Aizoaceae. In: Hubbard, C.E. \& E. MilneRedhead (ed.), Fl. Trop. E. Africa. 


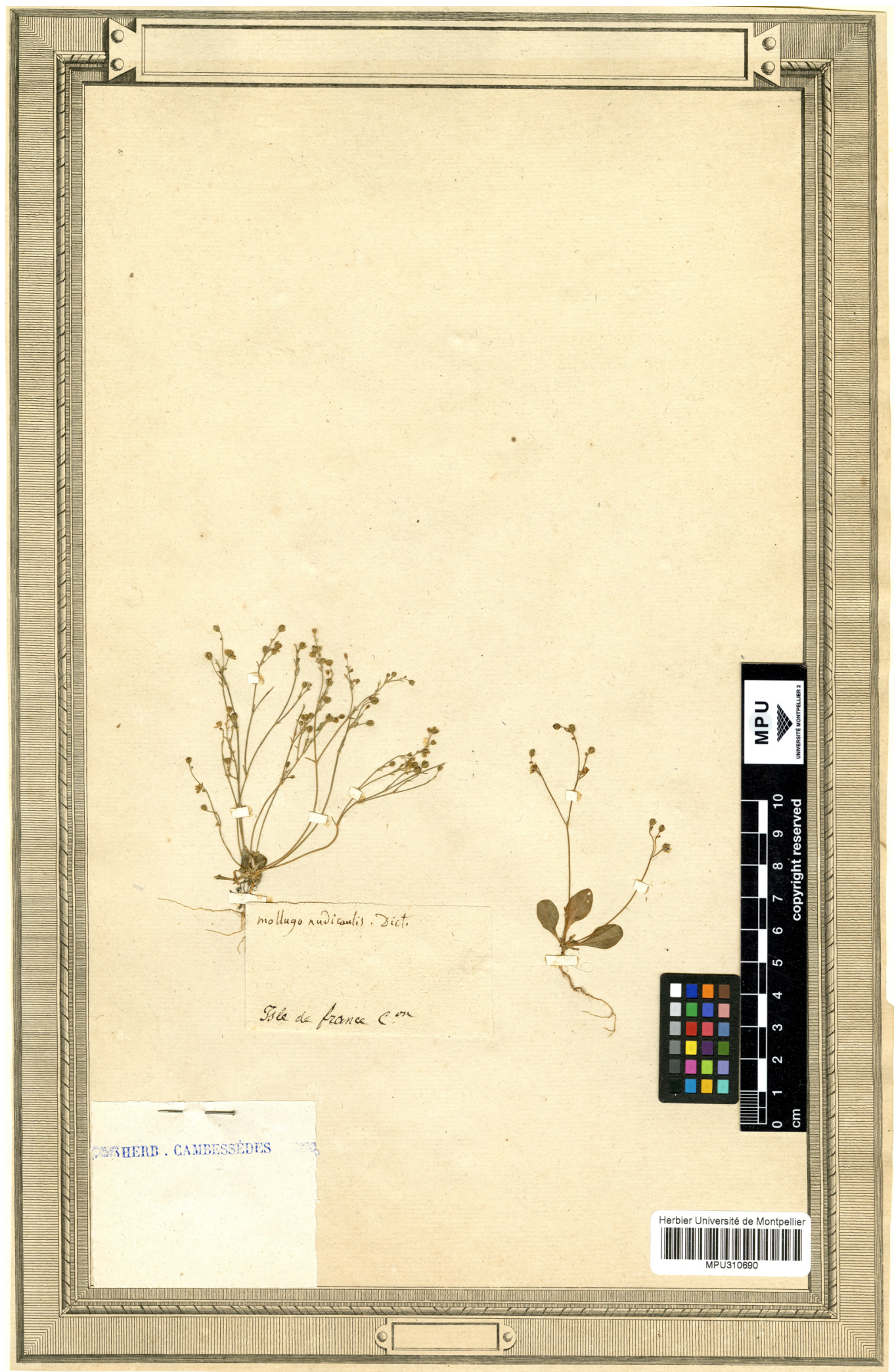

Fig. 1. - Lectotype of Mollugo nudicaulis Lam. [三 Paramollugo nudicaulis (Lam.) Thulin]. [Commerson s.n., MPU] [@ Herbier de l'Université de Montpellier] 
Lamarck, J.B. (1797). Encyclopédie méthodique, Botanique vol. 4. Paris.

Lourteig, A. (1966). L'herbier de Paul Hermann, base du Thesaurus Zeylanicus de Johan Burman. Taxon 15: 23-25.

NAsir, Y. (1973). Molluginaceae. In: NAsir, E. \& S.I. Ali, Fl. West Pakistan 40.

Sloane, H. (1707). A voyage to the Islands Madera, Barbados, Nieves, S. Christophers and Jamaica 1. London.

Stafleu, F.A. \& R.S. Cowan (1986). Taxonomic Literature ed. 2, 6. Regnum Veg. 115.

Sukhorukov, A.P. \& M. Kushunina (2016). Taxonomic revision and distribution of herbaceous Paramollugo (Molluginaceae) in the Eastern Hemisphere. PhytoKeys 73: 93-116.

Thulin, M., A.J. Moore, H. El-Seedi, A. Larsson, P.-A. Christin \& E.J. Edwards (2016). Phylogeny and generic delimitation in Molluginaceae, new pigment data in Caryophyllales, and the new family Corbichoniaceae. Taxon 65 : 775-793. 